\title{
Role of Fibronectin in Pneumocystis carinii Attachment to Cultured Lung Cells
}

\author{
Scott T. Pottratz and William J. Martin II \\ Division of Pulmonary and Critical Care, Department of Internal Medicine, Indiana University School of Medicine, \\ Indianapolis, Indiana 46202
}

\begin{abstract}
Attachment of pathogens to host cells is a prerequisite for the development of many infections. Pneumocystis carinii (PC) pneumonia is characterized by attachment of PC trophozoites to the alveolar epithelium. The mechanism of this process is unknown. Fibronectin (Fn) is a glycoprotein present in the alveolar space known to mediate cell-cell attachment, including the attachment of certain pathogens to host epithelial cells. In this study the binding of Fn to PC trophozoites has been characterized in vitro using ${ }^{125} \mathrm{I}-\mathrm{Fn}$. Fn binds saturably and specifically to $6.4 \times 10^{5}$ binding sites per organism with an apparent binding constant, $K_{d}$, of $1.2 \times 10^{-8} \mathrm{M}$. Fn binding to PC was inhibited by the addition of Arg-Gly-Asp-Ser (RGDS), a tetrapeptide containing the active site of the cell-binding domain of Fn. PC attachment to an alveolar epithelial cell line was quantified using ${ }^{51} \mathrm{Cr}$-labeled $\mathrm{PC}$ trophozoites. Attachment was decreased from $24 \pm 1.9 \%$ to $12.1 \pm 1 \%(P<0.01)$ by the addition of an anti-Fn antibody, an effect that could be overcome by the addition of excess free Fn. It is concluded that binding of Fn to PC may be an important initial step in the attachment of the organism to alveolar epithelial cells. Furthermore, it appears that $\mathrm{PC}$ recognizes and binds to the RGDS cell attachment site of Fn. (J. Clin. Invest. 1990. 85:351-356.) AIDS • binding • pneumonia • RGDS
\end{abstract}

\section{Introduction}

Pneumocystis carinii (PC) ${ }^{1}$ is a major cause of morbidity and mortality in immunocompromised hosts, especially in those with the acquired immunodeficiency syndrome. PC is an extracellular pathogen that binds tightly to alveolar epithelium, with a preference for type I alveolar epithelial cells (1-3). Electron microscopy has shown interdigitation of the cell membranes of PC and alveolar epithelial cells, but no actual membrane fusion (1-4). The mechanism of attachment between PC and host cells has not been clearly defined; however, current concepts suggest that the organism requires attachment to host cells to initiate PC replication and to induce the development

Address reprint requests to Dr. William J. Martin II, Indiana University Medical Center, 1001 W. 10th St., OPW 425, Indianapolis, IN 46202.

Received for publication 27 July 1989.

1. Abbreviations used in this paper: $\mathrm{Fn}$, fibronectin; $\mathrm{PC}$, Pneumocystis carinii; RGDS, arginine-glycine-aspartic acid-serine; RGES, arginineglycine-glutamic acid-serine.

J. Clin. Invest.

(C) The American Society for Clinical Investigation, Inc. $0021-9738 / 90 / 02 / 0351 / 06 \quad \$ 2.00$

Volume 85, February 1990, 351-356 of pneumonia $(1-3,5,6)$. Previous studies have shown that PC cytoskeletal function is necessary for attachment (6), and that mannose-containing membrane glycoproteins on the PC trophozoite may also be involved in the attachment process (7).

Fibronectin (Fn) is a $440-\mathrm{kD}$ glycoprotein dimer that is found in both soluble and cell-associated forms in the body (8-10). It is composed of two nearly identical subunits joined at the carboxyl end by disulfide linkages (8-10). Fn has been shown to have a role in the attachment of many pathogens to host tissue. These include staphylococci $(11,12)$, streptococci (13, 14), Treponema pallidum (15), Trypanosoma cruzi (16), Leishmania spp. (17), and Candida albicans (18). Staphylococci and streptococci bind to Fn at separate sites on the amino terminus of the molecule $(19,20)$. Other microorganisms make use of the cell binding domain of Fn $(15,21)$, which has been localized to the peptide sequence of Arg-Gly-Asp-Ser (RGDS) located toward the carboxy terminus of the molecule (22-24).

Fn is present in the alveolar spaces of both normal subjects and patients with active pulmonary inflammation (25). It is produced by activated alveolar macrophages (26) and type II alveolar epithelial cells (27). Histochemical studies suggest that cell-associated Fn is present on the surface of type I cells in vivo but not on the surface of type II cells (28). Fn binds to both the luminal and basal surfaces of the type I cell (28), suggesting that one of its functions involves attachment of the type I cell to the basal lamina. Similarly, PC organisms attach selectively to type I cells and not to type II cells, although the mechanism for this relative selectivity is unknown.

In the current study we have characterized the binding of ${ }^{125}$ I-Fn to PC trophozoites obtained from dexamethasonetreated rats. The ${ }^{125} \mathrm{I}-\mathrm{Fn}$ binding was specific as evidenced by inhibition of binding with excess unlabeled Fn. Addition of RGDS inhibited ${ }^{125}$ I-Fn binding to PC, whereas Arg-Gly-GluSer (RGES), a tetrapeptide with no effect on Fn cell binding $(29,30)$, had no effect on Fn binding to PC trophozoites. Furthermore, anti-Fn antibodies caused a significant decrease in PC adherence to A549 cells, an alveolar epithelial cell line. Each of these findings strongly supports a role for Fn in the attachment of PC to alveolar epithelial cells, and may suggest one mechanism for the selective attachment of PC to type I cells.

\section{Methods}

Isolation of PC. PC pneumonia was induced in pathogen-free rats by immunosuppression with dexamethasone and transtracheal inoculation of PC trophozoites as described by Bartlett et al. (31). Briefly, female Sprague-Dawley rats (150-175 g, Colony 202; Harlan Sprague Dawley, Inc., Indianapolis, IN) were housed in open cages and received water containing $2 \mathrm{mg} / \mathrm{ml}$ dexamethasone, $500 \mu \mathrm{g} / \mathrm{ml}$ tetracycline, and $200,000 \mathrm{U} / \mathrm{ml}$ nystatin ad lib. Rats were inoculated transtracheally with $1 \times 10^{6} \mathrm{PC}$ trophozoites $5-7 \mathrm{~d}$ after beginning immunosuppression. PC trophozoites were harvested 4-6 wk after 
inoculation when the rats were moribund with PC pneumonia. Rats were killed by intraperitoneal injection of T-61 euthanasia solution (Taylor Pharmaceutical, Decatur, IL), and the trachea was cannulated following a mid-line neck incision. The lungs were lavaged six times with 8-ml aliquots of HBSS plus $0.6 \mathrm{mM}$ EDTA, $100 \mathrm{U} / \mathrm{ml}$ penicillin, $100 \mu \mathrm{g} / \mathrm{ml}$ streptomycin, $4 \mu \mathrm{g} / \mathrm{ml}$ gentamicin, and $0.5 \mu \mathrm{g} / \mathrm{ml}$ amphotericin B. Approximately $40-45 \mathrm{ml}$ of lavage fluid was obtained from each rat.

PC was purified by a method adapted from Masur and Jones (32). The lavage fluid was centrifuged $(600 \mathrm{~g}$ for $10 \mathrm{~min}$ ) to pellet inflammatory and alveolar cells, and the supernatant was saved. The pellet was resuspended to prepare cytopreparation smears on a cytologic centrifuge (Cytospin II; Shandon Southern Instruments Inc., Sewickley, PA). The presence of PC cysts and trophozoites was verified using Gomori methenamine silver stain (33) and Diff-Quik stain (34). To obtain a highly purified population of PC trophozoites the supernatant was centrifuged $(1,400 \mathrm{~g}$ for $30 \mathrm{~min})$ and resuspended in $1 \mathrm{ml}$ of lavage fluid and PC trophozoites were quantified by the method of Bartlett et al. (35). A typical rat yielded 8-15 $\times 10^{6}$ trophozoites. Examination of the trophozoite suspension showed that PC organisms represented $\mathbf{9 7 - 9 8 \% ~ o f ~ c e l l u l a r ~ m a t e r i a l ~ i n ~ t h e ~ s u s p e n s i o n . ~ A n y ~ s a m p l e s ~ c o n t a i n i n g ~}$ bacterial, fungal, or inflammatory cell contamination were discarded.

${ }^{125}$ I-Fn binding to PC. The trophozoites were incubated for $18 \mathrm{~h}$ in DME (Whittaker, M. A. Bioproducts, Walkersville, MD) supplemented with $0.6 \mathrm{mg} / \mathrm{ml}$ glutamine, $100 \mathrm{U} / \mathrm{ml}$ penicillin, $100 \mu \mathrm{g} / \mathrm{ml}$ streptomycin, $0.5 \mu \mathrm{g} / \mathrm{ml}$ amphotericin $\mathrm{B}, 4 \mu \mathrm{g} / \mathrm{ml}$ gentamicin, and 0.6 mM EDTA. ${ }^{125}$ I-Fn (ICN Radiochemicals, Irvine, CA) binding to PC was quantified using the method of Proctor et al. (12). After the 18-h incubation the PC suspension was centrifuged $(1,400 \mathrm{~g}$ for $15 \mathrm{~min})$, the supernatant discarded, and the PC-rich pellet resuspended in DME at $20 \times 10^{6} / \mathrm{ml}$. Reaction mixtures containing $4 \times 10^{6} \mathrm{PC},{ }^{125} \mathrm{I}-\mathrm{Fn}(1.5-12$ $\mu \mathrm{g})$, and sample buffer $(0.02 \mathrm{M}$ Hepes and $1 \mathrm{mg} / \mathrm{ml} \mathrm{BSA}$ in $0.15 \mathrm{M}$ $\mathrm{NaCl}$ at $\mathrm{pH}$ 7.4) to a total volume of $1 \mathrm{ml}$ were incubated for $1 \mathrm{~h}$. Mixtures were centrifuged $(3,000 \mathrm{~g}$ for $2 \mathrm{~min})$ to pellet trophozoites, the supernatant was removed and saved, and the pellet was resuspended in $0.5 \mathrm{ml}$ of sample buffer. After a second centrifugation, the supernatant was again saved and added to the first supernatant. ${ }^{125} \mathrm{I}-\mathrm{Fn}$ in the pellet (bound) and in the supernatant (free) were quantified (5500 gamma-counter; Beckman Instruments, Inc., Palo Alto, CA). Specific binding was determined by addition of $125 \mu \mathrm{g}$ of unlabeled Fn (Sigma Chemical Co., St. Louis, MO) to the reaction mixture. Bound ${ }^{125} \mathrm{I}-\mathrm{Fn}$ was calculated as follows: bound ${ }^{125} \mathrm{I}-\mathrm{Fn}=\left(\mathrm{DPM}_{\text {pellet }} / \mathrm{DPM}_{\text {pellet }}\right.$ $\left.+\mathrm{DPM}_{\text {supernatant }}\right) \times{ }^{125} \mathrm{I}-\mathrm{Fn}$ added.

The effect of the tetrapeptides RGDS and RGES (Chemicon, El Segundo, CA) on ${ }^{125} \mathrm{I}-\mathrm{Fn}$ binding was determined by adding $500 \mu \mathrm{g}$ (1 $\mathrm{mM}$ ) of each tetrapeptide to a reaction mixture containing $3 \mu \mathrm{g}$ of ${ }^{125} \mathrm{I}-\mathrm{Fn}$. The assay was then performed as above. Bound ${ }^{125} \mathrm{I}-\mathrm{Fn}$ was determined and compared with that bound in the absence of the tetrapeptide.

PC adherence assay. PC adherence to an alveolar epithelial cell line was quantified using the method of Limper and Martin (6). Freshly isolated PC trophozoites were incubated for $18 \mathrm{~h}$ in $2 \mathrm{ml}$ of DME containing $0.5 \mathrm{ml}$ of FCS (Hyclone Laboratories, Logan, UT) and 50 $\mu \mathrm{Ci}$ of ${ }^{51} \mathrm{Cr}$ sodium chromate (New England Nuclear, Boston, MA). After incubation the ${ }^{51} \mathrm{Cr}$-labeled PC suspension was centrifuged $(1,400 \mathrm{~g}$ for $15 \mathrm{~min})$, the supernatant discarded, and the pellet resuspended in DME plus $10 \%$ FCS. The PC suspension was washed four times to remove unincorporated ${ }^{51} \mathrm{Cr}$ and resuspended in DME at a concentration of $20 \times 10^{6} / \mathrm{ml}$.

An alveolar epithelial cell line, A549 (CCL \#185; American Type Culture Collection, Rockville, MD), was used as the target cell population for PC adherence studies. A549 cells were grown to confluency in DME + $10 \%$ FCS on 24-well tissue culture dishes. $2 \times 10^{6}{ }^{51} \mathrm{Cr}$-labeled trophozoites were added to each well of A549 cells and incubated at $37^{\circ} \mathrm{C}$ for $4 \mathrm{~h}$. After the incubation, the media, containing nonadherent trophozoites, was removed and saved. The cell monolayer, containing bound trophozoites, was disrupted using 10\% Triton X-100 (Sigma Chemical Co.) and saved. ${ }^{51} \mathrm{Cr}$-Labeled PC organisms were quantified in each fraction (5500 gamma counter; Beckman Instruments, Inc.) and percent attachment expressed as follows: percent attachment $=(\mathrm{A} / \mathrm{A}+\mathrm{B}) \times 100$, where $\mathrm{A}={ }^{51} \mathrm{Cr}$-labeled PC bound to the A549 monolayer and $\mathrm{B}={ }^{51} \mathrm{Cr}$-labeled $\mathrm{PC}$ free in the media.

The effect of a polyclonal anti-rat Fn antibody (Calbiochem-Behring Corp., San Diego, CA) on adherence was assayed. ${ }^{51} \mathrm{Cr}$-Labeled trophozoites were incubated for $1 \mathrm{~h}$ in either DME alone or DME plus $0.2 \mathrm{mg}$ of the anti-Fn antibody. After the incubation of the trophozoites in the presence or absence of the anti-rat Fn antibody, the adherence assay was conducted as noted above. Specificity of the effect of the anti-Fn antibodies on PC adherence was demonstrated by addition of $125 \mu \mathrm{g}$ of free rat Fn (Calbiochem-Behring Corp.) to the assay. Attachment of ${ }^{51} \mathrm{Cr}$-labeled trophozoites was determined as noted above.

Statistics. Results are expressed as mean \pm SEM. Statistical analysis of the data was completed by $t$ test for paired observations. Statistical significance was accepted for $P<0.05$.

\section{Results}

The binding of ${ }^{125} \mathrm{I}-\mathrm{Fn}$ to $\mathrm{PC}$ trophozoites revealed that specific binding was saturable at higher ${ }^{125} \mathrm{I}-\mathrm{Fn}$ concentrations, while nonspecific and total binding continued to increase as additional ${ }^{125} \mathrm{I}$-Fn was added to the reaction mixture (Fig. 1). The saturation of specific binding became apparent at Fn concentrations $>5 \mu \mathrm{g} / \mathrm{ml}(25 \mathrm{nM})$. Plotting the data using the method of Scatchard (36) indicated that the number of Fn molecules bound per trophozoite was $\sim 6.4 \times 10^{5}$ with an apparent $K_{d}$ of $1.2 \times 10^{-8} \mathrm{M}$ (Fig. 2). The linearity of the plot suggests the existence of a homogeneous group of Fn binding sites on the trophozoite all displaying a similar affinity for Fn.

To further characterize the PC binding site on the Fn molecule, ${ }^{125} \mathrm{I}-\mathrm{Fn}$ binding studies were performed using the tetrapeptides RGDS and RGES. The addition of RGDS inhibited ${ }^{125} \mathrm{I}$-Fn binding to the trophozoites (Fig. 3). Bound ${ }^{125} \mathrm{I}$-Fn was reduced from $847 \mathrm{ng} /$ reaction mixture to $318 \mathrm{ng} /$ reaction mixture $(P<0.01)$ by the addition of $500 \mu \mathrm{g} / \mathrm{ml}(1 \mathrm{mM})$ RGDS. A similar decrease in bound ${ }^{125} \mathrm{I}-\mathrm{Fn}$ to $330 \mathrm{ng} /$ reaction mixture was produced by the addition of $125 \mu \mathrm{g} / \mathrm{ml}(0.6 \mu \mathrm{M})$ unlabeled whole Fn. The specificity of the RGDS inhibition of Fn binding to PC was demonstrated by the use of RGES, which differs from RGDS by the substitution of a single amino acid. This "false" peptide has been shown in other systems to have no effect on Fn binding $(29,30)$. Similarly, it had no effect on ${ }^{125} \mathrm{I}-\mathrm{Fn}$ binding to the PC trophozoites (Fig. 3).

The role of $\mathrm{Fn}$ in the adherence of PC trophozoites to monolayer A549 cells was assessed by the use of a polyclonal anti-rat Fn antibody (Fig. 4). Preincubation of the PC organisms with this antibody caused adherence to decrease from $24 \pm 1.9 \%$ to $12.1 \pm 1 \%(P<0.01)$, suggesting that Fn bound on the surface of the trophozoite plays a role in its adherence to alveolar epithelial cells. The specificity of this effect was demonstrated by addition of excess free Fn which reversed the inhibitory effect of the anti-Fn antibodies on PC adherence to the A549 monolayer.

PC adherence assays were also conducted in the presence of RGDS. However, RGDS interfered with the attachment of the A549 cell monolayer to the tissue culture plastic at RGDS concentrations as low as $50 \mu \mathrm{g} / \mathrm{ml}$ (data not shown) and thus prevented the direct use of this tetrapeptide in the adherence assay. Preincubation of PC organisms with $2 \mathrm{mM}(1,000$ $\mu \mathrm{g} / \mathrm{ml})$ RGDS with a subsequent wash to remove free tetrapeptide failed to affect PC adherence to the A549 cells (data 


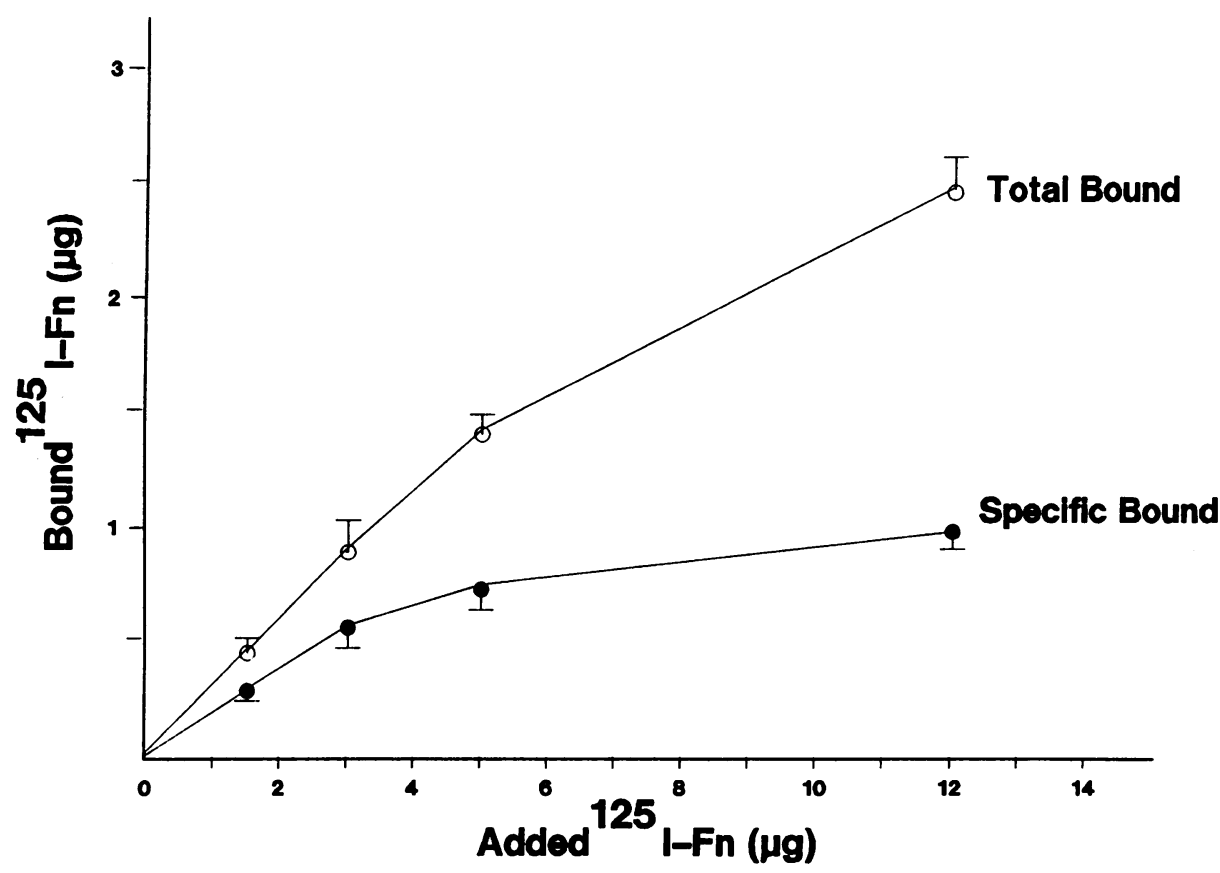

Figure 1. Total and specific binding of ${ }^{125} \mathrm{I}-\mathrm{Fn}$ to $\mathrm{PC}$. Binding assay was performed by the addition of $1.5-12 \mu \mathrm{g}$ ${ }^{125} \mathrm{I}-\mathrm{Fn}$ to $4 \times 10^{6} \mathrm{PC}$ for $1 \mathrm{~h}$. Specific binding was determined by the addition of $125 \mu \mathrm{g}$ of unlabeled Fn. Data are expressed as mean values of three separate experiments performed in duplicate, with error bar representing SEM. not shown). This finding is similar to those reported in other studies using RGDS in different model systems and indicates that interference of Fn mediated attachment by RGDS requires a significant molar excess of the tetrapeptide (30, $37,38)$.

\section{Discussion}

In this study Fn clearly binds to PC trophozoites in a saturable and specific manner. Through the use of Scatchard analysis, the approximate number of Fn binding sites on each trophozoite has been quantified. The linearity of the Scatchard plot suggests a homogeneous group of Fn binding sites, all displaying similar affinity for Fn. This is a characteristic of receptormediated binding, indicating the probable existence of a specific Fn receptor on the PC trophozoite.

The development of an in vitro method to quantify PC adherence to an alveolar epithelial cell line (6) permits the investigation of the possible role of Fn in PC attachment. The ability to block PC attachment by the use of specific anti-Fn antibodies implicates $\mathrm{Fn}$ as a mediator in this process. That adherence could not be completely abolished by anti-Fn antibody suggests that there may be additional factors involved in the mechanism of attachment.

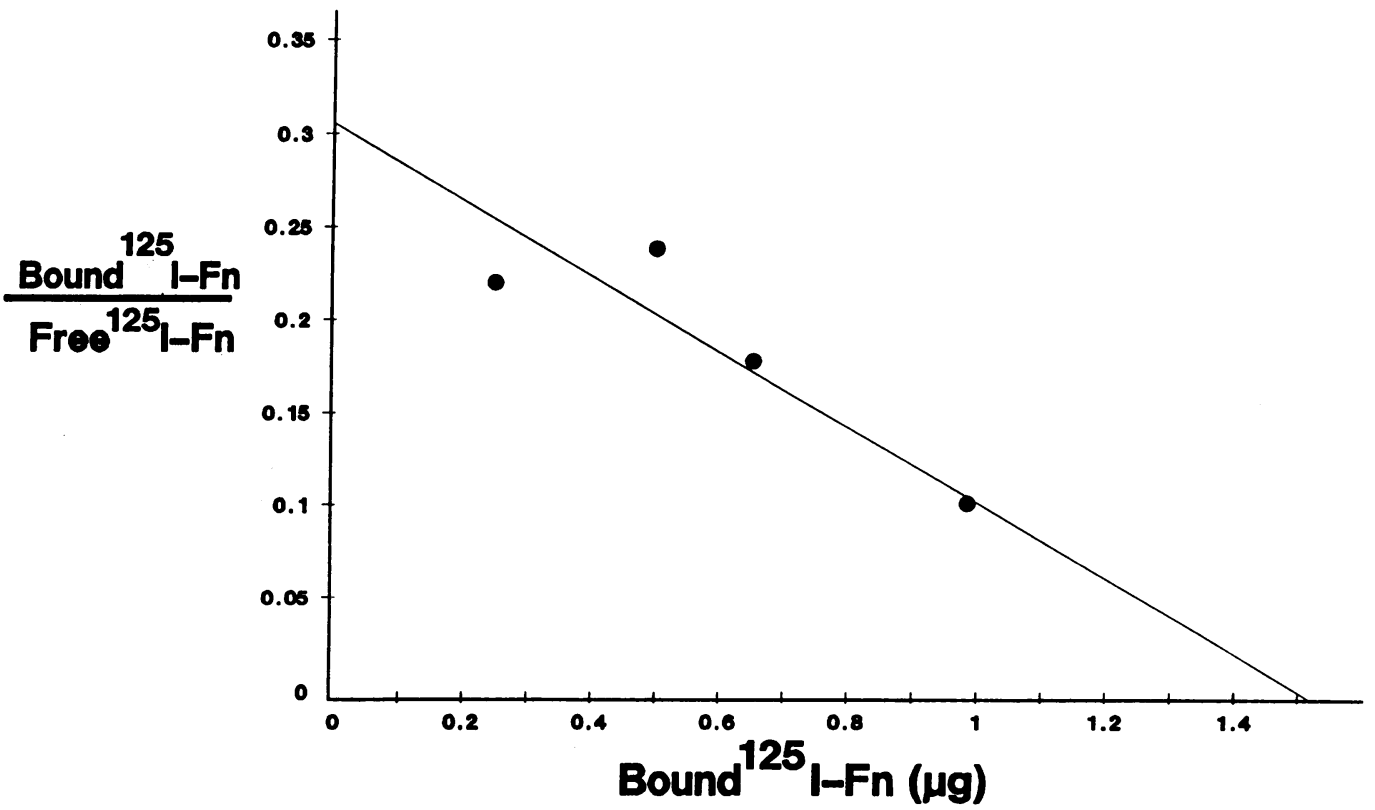

Figure 2. Scatchard plot of ${ }^{125}$ I-Fn binding to PC. Data are mean values obtained from Fig. 1. The slope of the line, 1.2 $\times 10^{-8}$, represents the association constant $\left(K_{d}\right)$ for Fn binding to PC. The number of Fn binding sites per organism was calculated from the $x$-intercept to be $6.4 \times 10^{5}$. Correlation coefficient of regression line, $r=-0.89$ 


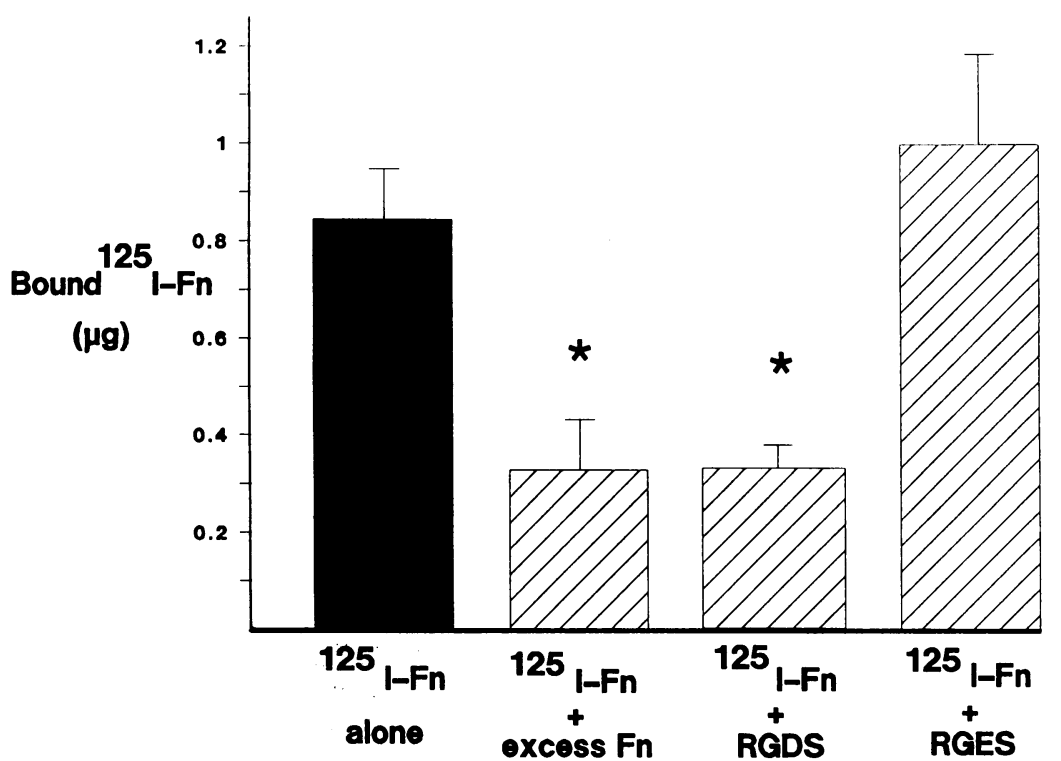

Figure 3. Effect of the tetrapeptides RGDS and RGES on ${ }^{125} \mathrm{I}$-Fn binding to PC. ${ }^{125} \mathrm{I}$-Fn binding assay was performed as in Fig. 1 with addition of 1 $\mathrm{mM}$ of either RGDS or RGES to the reaction mixture. Results are expressed as mean \pm SEM. ${ }^{*} P<0.01$.
Our data demonstrate that the site of attachment for Fn to $\mathrm{PC}$ involves the well-characterized cell-binding domain of Fn, localized to the tetrapeptide RGDS. The RGD component of this domain has previously been shown to mediate the attachment of many adhesive proteins to cells, including Fn (22-24), vitronectin (39), fibrinogen $(40,41)$, and von Willebrand factor (41). A group of receptors that recognize this peptide sequence, known as integrins (42), provide a mechanism for extracellular matrix proteins to interact with the cell cytoskeleton to facilitate cellular attachment $(42,43)$. Although several PC surface antigens have been described $(44,45)$, none have been sufficiently characterized to determine whether their structures resemble previously characterized integrins.

For many pathogens Fn provides a means of attachment to host cells. Fn binds to the surface of alveolar macrophages and type I alveolar epithelial cells, both of which are known to bind to $P C$ in vivo (1-3, 32). Type II cells, which do not bind Fn in vivo, are not a target cell for PC infection. The ability of PC to bind to Fn and use Fn in its attachment to the surface of the target cell may enable the PC trophozoite to become anchored within the alveolus, and permit the organism to initiate its infection. Binding to the alveolar epithelial surface may also aid in evading host defenses.

In summary, we have shown that PC trophozoites bind to radiolabeled Fn in a saturable and specific manner. This binding is inhibited by the peptide sequence RGDS, the active site in the cell-binding domain of Fn, demonstrating that this is the site of PC attachment to Fn. Adherence of PC trophozoites to an alveolar epithelial cell line can be inhibited by the addition of an anti-Fn antibody. These studies suggest a role for Fn as a

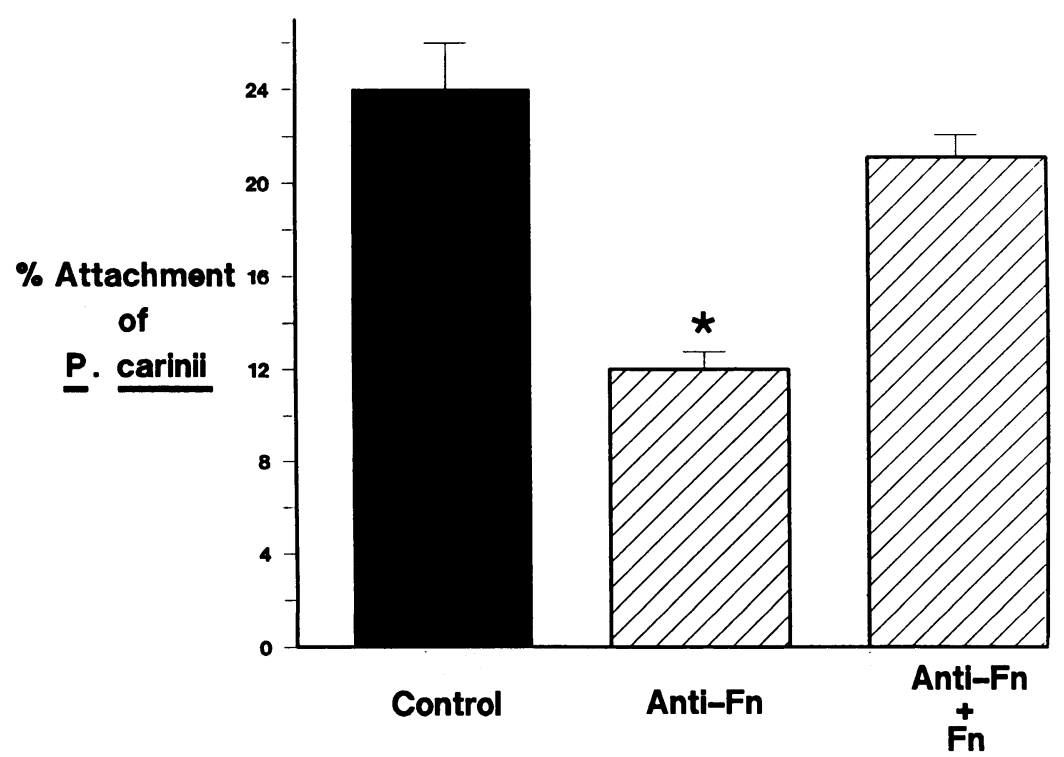

Figure 4. Effect of preincubation with polyclonal anti-Fn antibody on PC attachment to A549 cells. Attachment of ${ }^{51} \mathrm{Cr}$-labeled PC to the alveolar epithelial cell line, A549, was quantified after 4-h incubation of PC with A549 cell monolayer in the presence or absence of anti-Fn and in the presence or absence of added free Fn. Results are expressed as mean \pm SEM. ${ }^{*} P<0.01$. 
mediator of attachment for PC to the alveolar epithelium, a process that is essential to the development of active PC infection.

\section{Acknowledgments}

The technical assistance of Carrie A. Lynch and Lisa M. Pedigo is gratefully acknowledged.

This work was supported by a grant to Dr. Martin (RO1 HL/AI43524) from the National Institutes of Health. Dr. Pottratz is the recipient of the Sunnyside Guild Fellowship in Pulmonary Medicine.

\section{References}

1. Yoneda, K., and P. D. Walzer. 1983. Attachment of Pneumocystis carinii to Type I alveolar cells studied by freeze-fracture electron microscopy. Infect. Immun. 40:812-815.

2. Henshaw, N. G., J. L. Carson, and A. M. Culler. 1985. Ultrastructural observations of Pneumocystis carinii attachment to rat lung. J. Infect. Dis. 151:181-186.

3. Long, E. G., J. S. Smith, and J. L. Meier. 1984. Attachment of Pneumocystis carinii to rat pneumocytes. Lab. Invest. 54:609-615.

4. Sueishi, K., S. Hisano, A. Sumiyoshi, and K. Tanaka. 1977. Scanning and transmission electron microscopic study of human pulmonary pneumocystosis. Chest. 72:213-215.

5. Yoneda, K., and P. D. Walzer. 1981. Mechanism of pulmonary alveolar injury in experimental Pneumocystis carinii pneumonia in the rat. Br. J. Exp. Pathol. 62:339-346.

6. Limper, A. H., and W. J. Martin II. 1988. Pneumocystis carinii: evidence for direct lung cell toxicity and dependence on parasite-host cell attachment. Clin. Res. 36:507a. (Abstr.)

7. Limper, A. H., and W. J. Martin II. 1989. Pneumocystis carinii: concanavalin A alters parasite adherence to cultured lung cells. Am. Rev. Respir. Dis. 139:A127. (Abstr.)

8. Ruoslahti, E. 1988. Fibronectin and its receptors. Annu. Rev. Biochem. 57:375-413.

9. Mosher, D. F. 1984. Physiology of fibronectin. Annu. Rev. Med. 35:561-575.

10. Hynes, R. 1985. Molecular biology of fibronectin. Annu. Rev. Cell Biol. 1:67-90.

11. Kuusela, P. 1978. Fibronectin binds to Staphylococcus aureus. Nature (Lond.). 276:718-720.

12. Proctor, R. A., D. F. Mosher, and P. J. Olbrantz. 1982. Fibronectin binding to Staphylococcus aureus. J. Biol. Chem. 257:1478814794.

13. Simpson, W. A., and E. H. Beachey. 1983. Adherence of group A streptococci to fibronectin on oral epithelial cells. Infect. Immun. 39:275-279.

14. Lawrence, J. H., D. L. Hasty, and W. A. Simpson. 1988. Adherence of Streptococcus sanguis to conformationally specific determinants on fibronectin. Infect. Immun. 56:2279-2285.

15. Thomas, D. D., J. B. Baseman, and J. F. Aldrete. 1985. Fibronectin mediates Treponema pallidum cytadherence through recognition of fibronectin cell binding domain. J. Exp. Med. 161:514-525.

16. Ouaissi, M. A., D. Afchain, A. Capron, and J. A. Grimaud. 1984. Fibronectin receptors on Trypanasoma cruzi trypomastigotes and their biological function. Nature (Lond.). 308:380-382.

17. Wyler, D. J., J. P. Sypek, and J. A. McDonald. 1985. In vitro parasite-monocyte interactions in human leishmaniasis: possible role of fibronectin in parasite attachment. Infect. Immun. 49:305-311.

18. Kalo, A., E. Segal, E. Sahar, and D. Dayan. 1988. Interaction of Candida albicans with genital mucosal surfaces: involvement of fibronectin in adherence. J. Infect. Dis. 157:1253-1256.
19. Mosher, D. F., and R. A. Proctor. 1980. Binding and Factor XIII $_{\mathrm{a}}$-mediated cross-linking of a 27 kilodalton fragment of fibronectin to Staphylococcus aureus. Science (Wash. DC). 209:927-929.

20. Kuusela, P., T. Vartio, M. Vuento, and E. B. Myhre. 1984. Binding site for streptococci and staphylococci in fibronectin. Infect. Immun. 45:433-436.

21. Ouaissi, M. A., J. Cornette, D. Afchain, A. Capron, H. Grasmasse, and A. Tartar. 1986. Trypanasoma cruzi infection inhibited by peptides modeled from a fibronectin cell attachment domain. Science (Wash. DC). 221:603-607.

22. Pierschbacher, M. D., E. G. Hayman, and E. Ruoslahti. 1981. Location of the cell attachment site in fibronectin with monoclonal antibodies or proteolytic fragment of the molecule. Cell. 26:259-267.

23. Pierschbacher, M. D., and E. Ruoslahti. 1984. Cell attachment activity of fibronectin can be duplicated by small synthetic fragments of the molecule. Nature (Lond.). 309:30-33.

24. Akiyama, S. K., and K. M. Yamada. 1985. Synthetic peptides competitively inhibit both direct binding to fibroblasts and functional biological assays for the purified cell-binding domain of fibronectin. $J$. Biol. Chem. 260:10402-10405.

25. Rennard, S. I., and R. G. Crystal. 1981. Fibronectin in human bronchopulmonary lavage fluid. J. Clin. Invest. 69:113-122.

26. Rennard, S. I., G. W. Hunninghake, P. B. Bitterman, and R. G. Crystal. 1981. Production of fibronectin by the human alveolar macrophage: mechanism for the recruitment of fibroblasts to sites of tissue injury in interstitial lung diseases. Proc. Natl. Acad. Sci. USA. 78:7147-7151

27. Sage, H., F. M. Facia, G. E. Striker, and A. B. Fisher. 1983. Granular pneumocytes in primary culture secrete several major components of the extracellular matrix. Biochemistry. 22:2148-2155.

28. Rosenkrans, W. A., J. T. Albright, R. E. Hausman, and D. P. Penny. 1983. Ultrastructural immunocytochemical localization of fibronectin in developing rat lung. Cell Tissue Res. 234:165-177.

29. Pierschbacher, M. D., and E. Ruoslahti. 1984. Variants of the cell recognition site of fibronectin that retain attachment-promoting activity. Proc. Natl. Acad. Sci. USA. 81:5985-5988.

30. Yamada, K. M., and D. W. Kennedy. 1985. Amino acid sequence specificities of an adhesive recognition signal. J. Cell. Biochem. 28:99-104.

31. Bartlett, M. S., J. A. Fishman, S. F. Queener, M. M. Durkin, M. A. Jay, and J. W. Smith. 1988. New rat model of Pneumocystis carinii pneumonia. J. Clin. Microbiol. 26:1100-1102.

32. Masur, H., and T. C. Jones. 1978. The interaction in vitro of Pneumocystis carinii with macrophages and L-cells. J. Exp. Med. 147:157-170.

33. Brinn, N. T. 1975. Rapid metallic histological staining. J. Histotechnol. 6:125-129.

34. Cushion, M. T., and P. D. Walzer. Growth and serial passage of Pneumocystis carinii in A549 cell line. Infect. Immun. 44:245-251.

35. Bartlett, M. S., P. A. Vervanec, and J. W. Smith. 1979. Cultivation of Pneumocystis carinii with WI-38 cells. J. Clin. Microbiol. 10:796-799.

36. Scatchard, G. 1949. The attractions of proteins for small molecules and ions. Ann. NY Acad. Sci. 51:660-672.

37. Hayman, E. G., M. D. Pierschbacher, and E. Ruoslahti. 1985. Detachment of cells from culture substrate by soluble fibronectin peptides. J. Cell Biol. 100:1948-1954.

38. Cierniewski, C. S., M. Swiatkowska, J. Poniatowski, and J. Niewiarowska. 1988. Anti-(Arg-Gly-Asp-Ser) antibody and its interaction with fibronectin, fibrinogen and platelets. Eur. J. Biochem. 177:109-115.

39. Pytela, R., M. D. Pierschbacher, and E. Ruoslahti. 1985. A 125/115-kDa cell surface receptor specific for vitronectin interacts with the arginine-glycine-aspartic acid adhesion sequence derived from fibronectin. Proc. Natl. Acad. Sci. USA. 82:5766-5770. 
40. Plow, E. F., M. D. Pierschbacher, E. Ruolahti, G. A. Marguerie, and M. H. Ginsburg. 1985. The effect of Arg-Gly-Asp-containing peptides on fibrinogen and von-Willebrand factor binding to platelets. Proc. Natl. Acad. Sci. USA. 82:8057-8061.

41. Gantner, J. K., and J. S. Bennett. 1985. The tetrapeptide analog of the cell attachment site of fibronectin inhibits platelet aggregation and fibrinogen binding to activated platelets. J. Biol. Chem. 260:11891-11894.

42. Tamkun, J. W., D. W. DeSimone, D. Fonda, R. S. Patel, C. Buck, A. F. Horwitz, and R. O. Hynes. 1986. Structure of integrin, a glycoprotein involved in the transmembrane linkage between fibronectin and actin. Cell. 46:271-282.
43. Ruoslahti, E., and M. D. Pieschbacher. 1987. New perspectives in cell adhesion: RGD and integrins. Science (Wash. DC). 238:491497.

44. Graves, D. C., S. J. N. McNabb, M. A. Worley, J. D. Downs, and M. H. Ivey. 1986. Analysis of rat Pneumocystis carinii antigens recognized by human and rat antibodies by using western immunoblotting. Infect. Immun. 54:96-103.

45. Pesanti, E. C., and J. D. Shanley. 1988. Glycoproteins of Pneumocystis carinii: characterization by electrophoresis and microscopy. J. Infect. Dis. 158:1353-1359. 